\title{
Solitary Plasmacytoma of the Proximal Humerus
}

Issam Lalya* and Hamid Mansouri

Department of Radiation Oncology, Military Teaching Hospital of Rabat, Mohammed V University, Rabat-Morocco

"Corresponding author: Issam Lalya, Department of Radiation Oncology, Military Teaching Hospital of Rabat, Mohammed V University, Rabat, Morocco, Tel: 00212661572770; E-mail: issamlalya@yahoo.fr

Rec date: February 21,2016 Acc date: February 24,2016 Pub date: February 26,2016

Copyright: (c) 2016 Issam L, et al. This is an open-access article distributed under the terms of the Creative Commons Attribution License, which permits unrestricted use, distribution, and reproduction in any medium, provided the original author and source are credited.

\section{Clinical Images}

A 65 year-old-woman presented to our hospital for a 4 months history of pain in the left shoulder with limitation of movements. Plan radiographs showed a lytic lesion of the upper third of the left humerus without fracture (Figure 1).

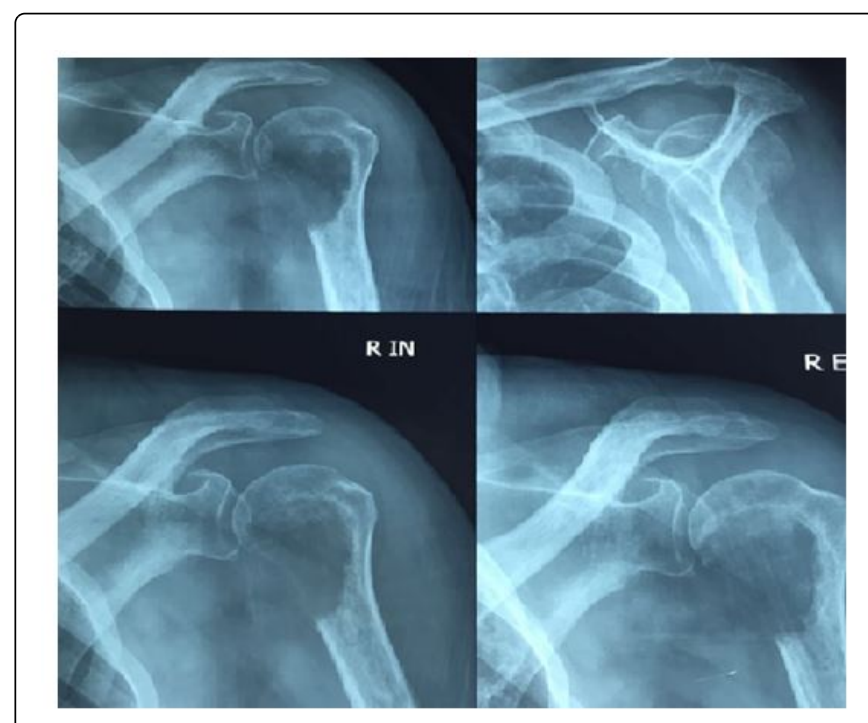

Figure 1: Lytic lesion of the upper third of the left humerus.

Magnetic resonance imaging revealed a lytic and enhancing lesion measuring $4,5 \times 5 \mathrm{~cm}$ in diameter, with extension into the adjacent soft tissues and scapula. Bone scan and MRI (Figure 2).

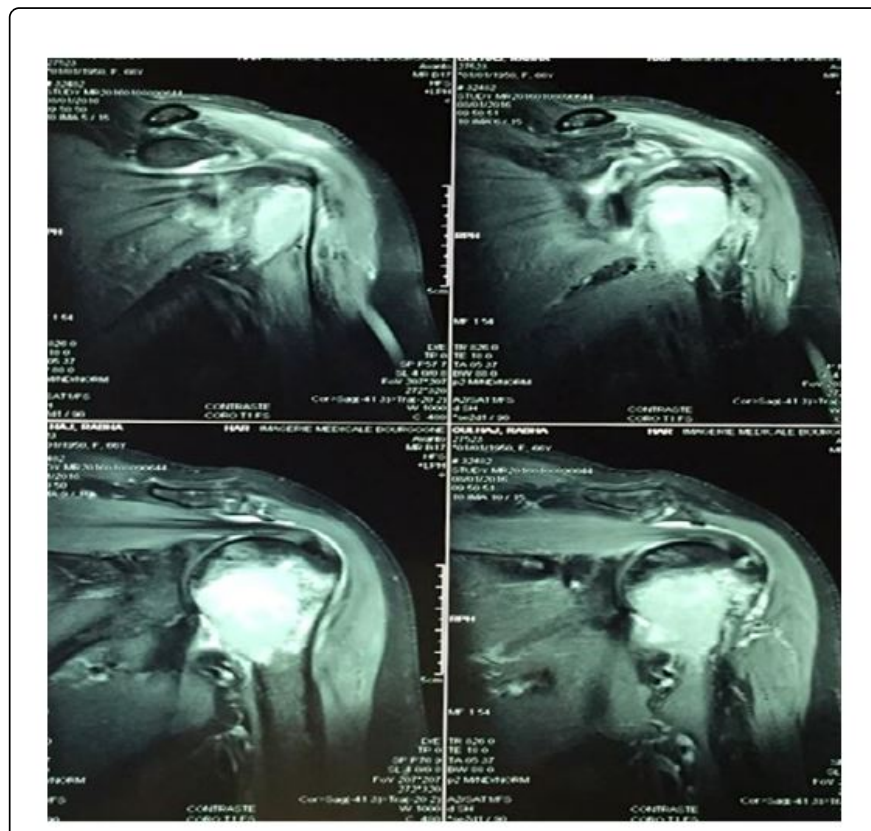

Figure 2: MR imaging showing destructive and enhancing mass of the humerus.

MR imaging showing destructive and enhancing mass of the humerus performed, and histopatholgic findings confirmed the diagnosis of plasmacytoma. Complete blood count, serum calcium, and creatinine were normal. Bone marrow aspirate found less than $10 \%$ monoclonal plasma cells. M-protein was absent in both serum and urine protein electrophoresis. The final diagnosis of solitary plasmacytoma was retained. The patient is actually receiving treatment by radiation therapy at the dose of $50 \mathrm{~Gy}$. 